\title{
N-Desulfated/Acetylated Heparin Ameliorates the Progression of Renal Disease in Rats with Subtotal Renal Ablation
}

\author{
Mabel L. Purkerson, Douglas M. Tollefsen, and Saulo Klahr \\ Renal Division and Division of Hematology-Oncology, Washington University School of Medicine, St. Louis, Missouri 63110
}

\section{Abstract}

The effect of administration of N-desulfated/acetylated heparin, almost completely devoid of anticoagulant activity, on the progression of renal disease was examined in rats with $13 / 4$ nephrectomy. Three groups of rats with $13 / 4$ nephrectomy were studied. Group I (control, $n=11$ ) received $0.15 \mathrm{ml}$ of $0.15 \mathrm{M}$ $\mathrm{NaCl}$ subcutaneously twice daily for $5 \mathrm{wk}$; group $2(n=11)$ received $0.15 \mathrm{ml}$ twice daily of $\mathrm{N}$-desulfated/acetylated heparin $(5.4 \mathrm{mg} / \mathrm{ml} ;<0.5 \mathrm{U} / \mathrm{ml})$; group $3(n=9)$ received $0.15 \mathrm{ml}$ twice daily of standard beef lung heparin $(5.4 \mathrm{mg} / \mathrm{ml} ; 977$ $\mathrm{U} / \mathrm{ml}$ ). Clearances and renal histological studies were done at the end of $5 \mathrm{wk}$ of heparin or saline administration. Rats given the heparin preparations had significantly higher inulin clearances $(2.55 \pm 0.38 \mathrm{ml} / \mathrm{min}$ per body weight $(B W)$ for group 2 , or $2.60 \pm 0.24 \mathrm{ml} / \mathrm{min}$ per $\mathrm{kg} \mathrm{BW}$ for group 3) than control rats $(1.59 \pm 0.20 \mathrm{ml} / \mathrm{min}$ per $\mathrm{kg} \mathrm{BW})$. Histological analysis revealed a greater number of glomeruli with segmental or global sclerosis, hyalinosis, or fibrosis $(36.6 \%)$ in control rats than in rats receiving $\mathrm{N}$-desulfated/acetylated heparin $(6.2 \%)$ or standard heparin (3.0\%). Blood pressure averaged $169.4 \pm 6.2 \mathrm{mmHg}$ in controls, 119.1 \pm 6.1 in rats of group 2 , and 124.3 \pm 2.5 in rats of group 3. The values for blood pressure were significantly lower in the two groups receiving heparin than in controls. These studies indicate that a heparin preparation, almost completely devoid of anticoagulant properties, affords the same degree of protection against progression of renal disease as does standard heparin in rats with subtotal renal ablation. It is suggested that other biological properties of heparin may be responsible for the effects observed.

\section{Introduction}

The experimental model of uremia produced by marked reduction of renal mass in the rat has been widely used. Reduction of renal mass in the rat results in functional hypertrophy and morphologic injury to the nephrons throughout the remnant kidney $(1,2)$; alterations can be detected within one week after severe renal ablation (3). Progressive glomerular damage ensues, with eventual glomerulosclerosis, proteinuria, hypertension, uremia, and death $(1,2)$. The glomerular pathology is initially focal and includes capillary thrombosis and an accumulation of amorphous material in the glomerulus. Progres-

Address reprint requests to Dr. Klahr, Washington University School of Medicine, Dept. of Medicine, Renal Div., Box 8126, 660 S. Euclid, St. Louis, MO 63110.

Received for publication 13 May 1987 and in revised form 7 July 1987.

J. Clin. Invest.

(c) The American Society for Clinical Investigation, Inc.

0021-9738/88/01/0069/06 $\$ 2.00$

Volume 81, January 1988, 69-74 sion of the renal lesion appears to be mediated in part by thrombotic mechanisms and is prevented by the administration of heparin and warfarin $(2,4,5)$. Heparin reduces blood pressure, improves renal function, and ameliorates markedly the histological changes seen in this model of subtotal renal ablation $(2,5,6)$. Although warfarin provides some beneficial effects in this model, the protection afforded by this drug is not as great as that seen with heparin administration (5). This suggested that heparin may exert its effect through mechanisms other than anticoagulation. Heparin has many pharmacologic effects that could modify the course of the glomerular lesions in this model $(7,8)$. To examine whether or not the anticoagulant properties of heparin are necessary to prevent the progression of renal disease in this experimental animal model, we examined the effects of $\mathrm{N}$-desulfated/acetylated heparin on the progression of renal disease in rats with subtotal renal ablation. The results indicate that $\mathrm{N}$-desulfated/acetylated heparin, almost completely devoid of anticoagulant activity, can prevent the progression of renal disease in rats with subtotal renal ablation.

\section{Methods}

Clearance studies. Studies of renal function were performed in 31 adult, female Sprague-Dawley (Holtzman) rats weighing 235-350 g. All animals were fed a standard rat chow containing $22.8 \%$ protein (rat chow; Ralston Purina Co., St. Louis, MO) and allowed tap water ad lib. unless otherwise stated. Renal mass was reduced (13/4 nephrectomy) as has been previously described (2). After reduction in renal mass, the rats were divided into three groups. A group of 11 rats (group 1) served as controls and were not given heparin but received instead $0.15 \mathrm{ml}$ of $0.15 \mathrm{M} \mathrm{NaCl}$ subcutaneously twice daily. A group of 11 rats (group 2) received $0.15 \mathrm{ml}$ of $\mathrm{N}$-desulfated/acetylated heparin $(5.4 \mathrm{mg} / \mathrm{ml},<0.5$ $\mathrm{U} / \mathrm{ml}$ ) twice daily for $5 \mathrm{wk}$. Another group of nine rats received $0.15 \mathrm{ml}$ of beef lung heparin $(5.4 \mathrm{mg} / \mathrm{ml}, 977 \mathrm{U} / \mathrm{ml}$ twice daily subcutaneously (group 3). At the end of $5 \mathrm{wk}$ the heparin or the vehicle was discontinued for $24 \mathrm{~h}$ before clearance studies.

Anticoagulation studies. For these studies an additional group of 15 rats had $13 / 4$ nephrectomy. $2 \mathrm{wk}$ after the surgical procedure to reduce renal mass, the animals were divided into three groups of five rats each. Rats in the control group received $0.15 \mathrm{ml}$ of $0.15 \mathrm{M} \mathrm{NaCl}$ subcutaneously at 12 -h intervals for three doses. The other two groups received either $0.15 \mathrm{ml}$ of standard beef lung heparin or $0.15 \mathrm{ml}$ of N-desulfated/acetylated heparin at $12-\mathrm{h}$ intervals for three doses. Similar groups of normal rats (not subjected to subtotal renal ablation) were treated in the same manner $(n=16) .2 \mathrm{~h}$ after the last dose of subcutaneous saline or heparin, blood was collected from the aorta of normal rats or rats with $13 / 4$ nephrectomy into tubes containing sodium citrate which were placed in ice. Samples to determine activated partial thromboplastin time (aPTT) ${ }^{1}$ were processed as described below.

Preparation of $\mathrm{N}$-desulfated acetylated heparin. N-desulfated heparin was prepared according to the method of Inoue and Nagasawa (9). Briefly, $1.6 \mathrm{~g}$ of beef lung sodium heparinate (VHA Plus; LyphoMed,

1. Abbreviations used in this paper: aPTT, activated partial thromboplastin time; BW, body weight; PAH, paraaminohippurate. 
Inc., Chicago, IL) was converted to the acid form on a 50-ml Dowex $50 \mathrm{~W}\left(\mathrm{H}^{+}\right.$form $)$column, neutralized with pyridine, and lyophilized. The pyridinium salt was then incubated with $300 \mathrm{ml}$ of $5 \%$ methanol in dimethyl sulfoxide for $1.5 \mathrm{~h}$ at $50^{\circ} \mathrm{C}$. The solution was diluted with an equal volume of water and the $\mathrm{pH}$ adjusted to $\sim 9$ with $\mathrm{NaOH}$. The $\mathrm{N}$-desulfated heparin was then dialyzed against water and lyophilized. $\mathrm{N}$-acetylation was performed according to the procedure of Hook et al. (10). The $\mathrm{N}$-desulfated heparin $(1.14 \mathrm{~g}$ ) was dissolved in $80 \mathrm{ml}$ of 0.05 $\mathrm{M} \mathrm{Na}_{2} \mathrm{CO}_{3}$ in $10 \%$ methanol and stirred in a melting ice bath. Six times during $1 \mathrm{~h} 12 \mathrm{ml}$ of acetic anhydride was added. The $\mathrm{pH}$ was maintained at 7.0 to 7.5 by addition of $10 \%$ methanol saturated with $\mathrm{Na}_{2} \mathrm{CO}_{3}$. The final product was dialyzed against water, lyophilized, and dissolved in $0.15 \mathrm{M} \mathrm{NaCl}$. N-desulfated/acetylated heparin and untreated heparin were dialyzed extensively against $0.15 \mathrm{M} \mathrm{NaCl}$ and the concentration of each was adjusted to $5.4 \mathrm{mg} / \mathrm{ml}$ as determined by the carbazole assay for uronic acid (11). The preparations were sterilized by filtration through a $0.2-\mu \mathrm{m}$ membrane (Nalgene Labware Div., Nalge Co., Div. of Sybron Corp., Rochester, NY).

Determination of in vitro anticoagulant activity of heparin. The anticoagulant activities of control and $\mathrm{N}$-desulfated/acetylated heparin were determined in a thrombin inhibition assay with purified antithrombin III. Human antithrombin III and thrombin were prepared as previously described (12). $5 \mu \mathrm{l}$ of antithrombin III $(50 \mu \mathrm{g} / \mathrm{ml})$ was incubated with $90 \mu \mathrm{l}$ of the heparin sample diluted in $0.15 \mathrm{M} \mathrm{NaCl}, 20$ $\mathrm{mM}$ Tris- $\mathrm{HCl}$, and $0.1 \%$ polyethylene glycol, $\mathrm{pH} 7.4$, for $2 \mathrm{~min}$ at room temperature. $5 \mu \mathrm{l}$ of thrombin $(\sim 8 \mathrm{U} / \mathrm{ml})$ was then added, the solution was incubated for exactly $1 \mathrm{~min}$, and the remaining thrombin activity was determined by addition of $100 \mu \mathrm{l}$ of $0.1 \mathrm{mM}$ tosyl-GlyPro-Arg-p-nitroanilide (Boehringer Mannheim Biochemicals, Indianapolis, IN). Hydrolysis of the substrate was terminated after 2 min by addition of $10 \mu \mathrm{l}$ of hirudin ( $200 \mathrm{U} / \mathrm{ml}$, Sigma Chemical Co., St. Louis, $\mathrm{MO}$ ), and the absorbance at $405 \mathrm{~nm}$ was recorded. The assay was standardized with porcine intestinal heparin of known activity. The untreated beef lung heparin had a specific activity of $180 \mathrm{U} / \mathrm{mg}$, while the $\mathrm{N}$-desulfated/acetylated heparin had a specific activity of $\leq 0.1 \mathrm{U} / \mathrm{mg}$.

$a P T T$. Rat blood was drawn from the aorta and immediately placed in 5-ml Vacutainer tubes (6418; Bectin-Dickinson \& Co., Sunnyvale, CA) containing sodium citrate. Cells were removed by centrifugation and the plasma was stored at $-20^{\circ} \mathrm{C}$ before use. Plasma (100 $\mu$ ) was incubated for $3 \mathrm{~min}$ at $37^{\circ} \mathrm{C}$ with $100 \mu \mathrm{l}$ of prewarmed aPTT reagent (Thrombosil I; Ortho Diagnostic Systems Inc., Raritan, NJ) in a fibrometer (Bectin-Dickinson \& Co.). The clotting time (i.e., the aPTT) was determined after addition of $100 \mu$ l of prewarmed $20 \mathrm{mM}$ $\mathrm{CaCl}_{2}$.

Measurement of GFR and renal plasma flow. On the day of study, animals were anesthetized lightly with ether for placement of catheters into the bladder, femoral artery, and tail vein for the infusion of solutions containing inulin and paraaminohippurate (PAH). The animals were placed in Plexiglas holders and 1.5-2 $\mathrm{h}$ were allowed for recovery from anesthesia. After a priming dose of chemical inulin (Fisher Scientific Co., Pittsburgh, PA) and chemical PAH (Merck Sharp \& Dohme, Div. of Merck \& Co., Inc., West Point, PA), a sustaining infusion of inulin and PAH to maintain plasma levels were given at $39 \mu \mathrm{l} / \mathrm{min}$ for $1 \mathrm{~h}$ before the initiation of clearance studies. Three clearance periods were obtained with blood being drawn at the midpoint of each collection period.

Determination of urine protein, blood pressure, and other measurements. Urine protein excretion and mean arterial blood pressure were measured in all groups of rats. Before the performance of clearance studies, animals were placed in metabolic cages and allowed regular chow (pulverized) and water intake while urine collections were made for $24 \mathrm{~h}$. Upon completion of clearance studies, animals were briefly anesthetized with ether while cannulas were removed. Rats were returned to their cages and $2 \mathrm{~d}$ after completion of the clearance studies, while anesthetized with sodium pentobarbitol (Diabutol; $30 \mathrm{mg} / \mathrm{kg}$ body weight $[\mathrm{BW}])$, the mean arterial blood pressure was measured via the right femoral artery with PE 50 tubing connected to a mercury manometer. At the end of the experiments the rats were killed, the kidney and the heart were removed, and their weights recorded. Heart weight was used to calculate heart weight (in milligrams) to BW (per $100 \mathrm{~g}$ ) ratio, an indicator of the presence of sustained hypertension (13). Kidney histology was evaluated as described below. Clearances were calculated using standard techniques and measurements of inulin and PAH were calculated as previously described (14).

Histological evaluation of the remnant kidneys. Light microscopy to assess glomerular and small renal blood vessel morphology was performed in blinded fashion on midline, saggital, periodic acid Schiff-stained sections of the viable portion of the remnant kidney. At least 50 consecutive cortical glomeruli were counted. Each glomerulus was assigned to one of five categories based upon the degree of detectable morphological damage: 0 , no visible pathologic changes; I, mesangial deposits with some mesangial hypercellularity; II, appearance of focal areas of sclerosis and loop collapse in the glomerulus with or without generalized mesangial thickening; III, segmental sclerosis with loop collapse, and blebs in epithelial cells; and IV, global sclerosis, hyalinosis, and fibrosis. The number of glomeruli in each category was expressed as percentage of the total number of glomeruli counted for each rat (2).

Calculations. An unpaired Student's $t$ test was used when comparing data from control versus experimental rats. Analysis of variance was used for the histological data reported in Table IV.

\section{Results}

Anticoagulation studies. To determine the anticoagulant effect of standard and $\mathrm{N}$-desulfated/acetylated heparin in normal and subtotally nephrectomized rats, animals were given three doses of heparin or saline at 12-h intervals and the aPTT was then determined from an aortic blood sample (Table I). In both normal rats and rats with subtotal renal ablation, standard heparin prolonged the aPTT to longer than $120 \mathrm{~s}$. N-desulfated/acetylated heparin had no significant effect on the aPTT in normal rats but prolonged the aPTT in $13 / 4$ nephrectomized rats slightly but significantly compared with controls. Rats given $\mathrm{N}$-desulfated/acetylated heparin had remarkably and significantly shorter aPTTs than rats receiving standard heparin.

Assessment of renal function. Additional rats were given heparin or saline injections twice daily for $5 \mathrm{wk}$ after subtotal renal ablation. As shown in Table II, BW was not significantly

Table I. aPTT in Normal and $13 / 4$ Nephrectomized Rats Receiving Saline (Control), Standard Heparin, or N-Desulfated/ Acetylated Heparin

\begin{tabular}{lllll}
\hline & & $\frac{\text { Standard }}{n}$ & & N-desulfated/acetylated \\
\hline $\begin{array}{l}\text { Normal rats } \\
\begin{array}{l}13 / 4 \text { nephrectomized } \\
\text { rats }\end{array}\end{array}$ & $25.8 \pm 7.5$ & $>120^{*}$ & $26.0 \pm 2.7^{\ddagger}$ \\
\hline & $31.6 \pm 6.1$ & $>120^{*}$ & $42.9 \pm 7.5^{8}$ \\
\hline
\end{tabular}

Rats were given three doses of $0.15 \mathrm{ml} 0.15 \mathrm{M}$ saline, $0.15 \mathrm{ml}$ standard heparin, or $0.15 \mathrm{ml} \mathrm{N}$-desulfated/acetylated heparin at 12-h intervals. Blood was collected $2 \mathrm{~h}$ after the last dose as described in Methods. Values are in seconds and are given as the mean \pm standard deviation.

* Significantly different $(P<0.001)$ from control values.

₹ Not significantly different from control values.

Significantly different $(0.025>P>0.01)$ from control values. 
Table II. BW, Mean Arterial Blood Pressure, Ratio of Heart Weight to BW, and Blood-Urea Nitrogen in the Three Groups of Rats

\begin{tabular}{|c|c|c|c|c|}
\hline Groups & BW & Mean arterial blood pressure & $\frac{\text { Heart Weight }}{\mathrm{BW}} \times 100$ & BUN \\
\hline & 8 & $m m H g$ & & $m g / d l$ \\
\hline 1 Controls $(n=11)$ & $301.4 \pm 10.1$ & $169.4 \pm 6.2$ & $514.6 \pm 11.7$ & $70.2 \pm 6.7$ \\
\hline 2 N-desulfated/acetylated heparin $(n=11)$ & $304.1 \pm 6.7^{*}$ & $119.1 \pm 6.1^{\ddagger}$ & $424.7 \pm 14.5^{5}$ & $48.0 \pm 4.1^{\ddagger}$ \\
\hline 3 Standard heparin $(n=9)$ & $278 \pm 13.5^{*}$ & $124.3 \pm 2.5^{\ddagger}$ & $395.3 \pm 10.7^{\S}$ & $40.9 \pm 5.0^{\ddagger}$ \\
\hline
\end{tabular}

Rats were given twice daily injections of heparin or saline (control) for $5 \mathrm{wk}$ after $13 / 4$ nephrectomy. Values are given as the mean \pm standard error of the mean. BUN, Blood-urea nitrogen. * Not significantly different from control values $(P>0.05)$. ${ }^{\ddagger}$ Significantly different from control values $(P<0.01)$. SSignificantly different from control values $(P<0.001)$.

different in the three groups of rats: control, those receiving standard, or N-desulfated/acetylated heparin. Mean arterial blood pressure was significantly higher $(169.4 \pm 6.2 \mathrm{mmHg})$ in the control group than in the rats receiving either standard or $\mathrm{N}$-desulfated/acetylated heparin. There was no significant difference in mean arterial blood pressure of rats receiving $\mathrm{N}$-desulfated/acetylated heparin $(119.1 \pm 6.1 \mathrm{mmHg})$ compared with those receiving standard heparin $(124.3 \pm 2.5 \mathrm{mmHg})$. There was a significant difference $(P<0.001)$ in the ratio of heart weight to $\mathrm{BW}$ in control rats $(514.6 \pm 11.7)$ compared with those receiving $\mathrm{N}$-desulfated/acetylated or standard heparin (424.7 \pm 14.5 or $395.3 \pm 10.7)$. There was no significant difference in the ratio of heart weight to BW between the latter two groups. Blood-urea nitrogen levels were significantly greater in control rats when compared with the treated rats.

Table III shows the data for renal function in the three groups of rats. As compared with control rats receiving vehicle, both groups of rats given either standard heparin or N-desulfated/acetylated heparin had significantly higher values for inulin clearance. Inulin clearance averaged $1.59 \pm 0.20 \mathrm{ml} / \mathrm{min}$ per $\mathrm{kg} \mathrm{BW}$ in controls vs. $2.55 \pm 0.38 \mathrm{ml} / \mathrm{min}$ per $\mathrm{kg} \mathrm{BW}$ in animals receiving $\mathrm{N}$-desulfated/acetylated heparin and $2.60 \pm 0.24 \mathrm{ml} / \mathrm{min}$ per $\mathrm{kg} \mathrm{BW}$ in rats given standard heparin. The values for PAH clearance were higher but not significantly different in the rats receiving N-desulfated/acetylated heparin $(7.35 \pm 1.20 \mathrm{ml} / \mathrm{min}$ per $\mathrm{kg} \mathrm{BW})$ or standard heparin $(7.63 \pm 0.68 \mathrm{ml} / \mathrm{min}$ per $\mathrm{kg} \mathrm{BW})$ than in control rats $(5.56 \pm 0.76$ $\mathrm{ml} / \mathrm{min}$ per $\mathrm{kg} \mathrm{BW}$ ). The 24-h urinary excretion of protein was significantly lower in rats receiving $\mathrm{N}$-desulfated/acetylated heparin than in controls. As an average value, rats given stan- dard heparin had a similar degree of proteinuria as controls; however, this similar degree of proteinuria in heparin-treated rats and control rats was due to the very high excretion of protein in three of nine rats in the former group. These three rats had protein excretions of 488,627 , and $655 \mathrm{mg} / 24 \mathrm{~h}$, respectively. Two of these three rats had not only the highest degree of proteinuria of all rats studied but also the lowest hematocrit (30 and $32 \%$ as compared with hematocrits $>40 \%$ in the other rats). Therefore, it is possible that part of the heavy proteinuria, at least in two of these three rats, was related to hematuria. If these three rats are excluded, the mean excretion rate of protein of the remaining six rats would be $46.5 \pm 15.3$ $\mathrm{mg} / 24 \mathrm{~h}$ (range, 11 to $109 \mathrm{mg} / 24 \mathrm{~h}$ ), a value significantly different $(P<0.001)$ from that of untreated control rats. In the control group only one rat had a very high protein excretion $(550 \mathrm{mg} / 24 \mathrm{~h})$. If this rat is excluded the mean protein excretion of the remaining 10 rats in the control group (range, 148 to $387 \mathrm{mg}$ ) would be $219.7 \pm 27.4 \mathrm{mg} / 24 \mathrm{~h}$, a value significantly different $(P<0.01)$ from the mean value of $100.1 \pm 18.4 \mathrm{mg}$ in rats treated with $\mathrm{N}$-desulfated/acetylated heparin or the mean value of $46.5 \pm 15.3 \mathrm{mg} / 24 \mathrm{~h}$ of six of the nine rats treated with standard heparin.

Renal histology. Table IV shows the histology data for the three groups of rats. The percent of glomeruli with no visible pathologic changes (grade 0 ) or only mesangial deposits and mesangial proliferation (grade I) was considerably greater in animals given $\mathrm{N}$-desulfated/acetylated heparin $(91.0 \%)$ or standard heparin $(96.0 \%)$ than in control rats $(61.2 \%)$. On the other hand (see Fig. 1 and Table IV), the percent of glomeruli with severe histological abnormalities (grades III and IV) was

Table III. Renal Function in the Three Groups of Rats

\begin{tabular}{|c|c|c|c|c|}
\hline Groups & Urine flow & $C_{i}$ & $\mathrm{C}_{\mathrm{PAH}}$ & Urine protein \\
\hline & $\mu l / m i n$ & $\mathrm{ml} / \mathrm{min} / \mathrm{kg} \mathrm{BW}$ & $\mathrm{ml} / \mathrm{min} / \mathrm{kg} B W$ & $m g / 24 h$ \\
\hline 1 Control $(n=11)$ & $58 \pm 6$ & $1.59 \pm 0.20$ & $5.56 \pm 0.76$ & $254.7 \pm 41.4$ \\
\hline 2 N-desulfated/acetylated heparin $(n=11)$ & $69 \pm 8$ & $2.55 \pm 0.38^{*}$ & $7.35 \pm 1.20$ & $100.1 \pm 18.4^{*}$ \\
\hline 3 Standard heparin $(n=9)$ & $66 \pm 10$ & $2.60 \pm 0.24^{*}$ & $7.63 \pm 0.68$ & $227.8 \pm 92.4^{\ddagger}$ \\
\hline
\end{tabular}

Rats were prepared as described in Table II. $C_{i n}$, Inulin clearance; $C_{P A H}$, clearance of PAH. Values are given as the mean \pm standard error of the mean. * Values significantly different from control values $(P<0.01)$. Other values were not significantly different from control $(P>0.05)$. * The rather large standard error of the mean is due to the fact that three of the nine rats in this group had extremely high degrees of proteinuria $(488,627$, and $655 \mathrm{mg} / 24 \mathrm{~h}$, respectively). In the remaining six rats the excretion of protein ranged from 11 to $109 \mathrm{mg} / 24 \mathrm{~h} \mathrm{(mean} 46.5 \pm 15.3$ $\mathrm{mg} / 24 \mathrm{~h}$ ), a value significantly different from that obtained in control rats $(P<0.001)$ and rats treated with $\mathrm{N}$-desulfated/acetylated heparin $(P<0.05)$. 


\begin{tabular}{|c|c|c|c|c|c|}
\hline \multirow[b]{2}{*}{ Groups } & \multicolumn{5}{|c|}{ Histological grade } \\
\hline & 0 & I & II & III & IV \\
\hline & \multicolumn{5}{|c|}{ \% glomeruli examined } \\
\hline 1 Control & $49.7 \pm 6.0$ & $11.5 \pm 3.6$ & $2.2 \pm 1.2$ & $10.7 \pm 1.8$ & $25.9 \pm 5.2$ \\
\hline $2 \mathrm{~N}$-desulfated/acetylated heparin & $74.0 \pm 4.1$ & $17.0 \pm 3.1$ & $2.8 \pm 0.4$ & $4.0 \pm 0.7$ & $2.2 \pm 0.3$ \\
\hline 3 Standard heparin & $82.0 \pm 3.8$ & $14.0 \pm 4.2$ & $1.0 \pm 0$ & $2.0 \pm 0.7$ & $1.0 \pm 0.7$ \\
\hline \multicolumn{6}{|l|}{$\begin{array}{l}\text { Analysis of variance } \\
\text { ( } t \text { values of paired groups) }\end{array}$} \\
\hline$t(1$ vs. 2$)$ & -10.887 & -1.113 & -0.561 & 3.937 & 5.394 \\
\hline$P$ & 0.0001 & 0.2789 & 0.581 & 0.008 & 0.0001 \\
\hline$t(1$ vs. 3$)$ & -11.445 & 0.480 & 1.065 & 4.85 & 5.376 \\
\hline$P$ & 0.0001 & 0.637 & 0.301 & 0.001 & 0.0001 \\
\hline$t(2$ vs. 3$)$ & -1.117 & 0.576 & 1.597 & 1.115 & 0.259 \\
\hline$P$ & 0.279 & 0.572 & 0.128 & 0.280 & 0.799 \\
\hline
\end{tabular}

Each glomerulus was assigned to one of five categories based upon the degree of detectable morphological damage: 0 , no visible pathologic changes; I, mesangial deposits with some mesangial hypercellularity; II, appearance of focal areas of sclerosis and loop collapse in the glomerulus with or without generalized mesangial thickening; III, segmental sclerosis with loop collapse, and blebs in epithelial cells; and IV, global sclerosis, hyalinosis, and fibrosis.

significantly greater in control rats $(36.6 \%)$ than in rats receiving $\mathrm{N}$-desulfated/acetylated heparin $(6.2 \%)$ or standard hepa$\operatorname{rin}(3.0 \%)$.

\section{Discussion}

We have reported previously that heparin given subcutaneously to rats with subtotal renal ablation prevented glomerular capillary occlusion, reduced systemic blood pressure to near normal levels, and prevented azotemia (2). Therapy with beef lung heparin markedly decreased the number of sclerotic glomeruli from $\sim 40 \pm 7 \%$ in control animals given saline to $2 \pm 0.7 \%$ in the animals receiving $150 \mathrm{U}$ of heparin subcutaneously twice daily. This protective effect of heparin on renal function and histology in the $13 / 4$ nephrectomized model was confirmed by Olson (4), who reported results similar to ours (2). Olson (4) gave rats with subtotal renal ablation either intact heparin or a low molecular weight fraction of heparin with the same negative charge as the intact molecule but apparently

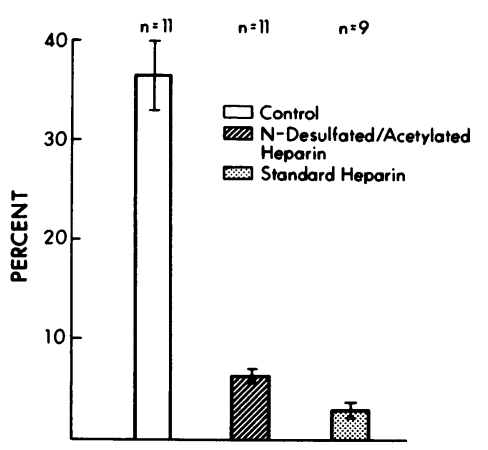

Figure 1. Percent of glomeruli with severe histological abnormalities (segmental sclerosis with loop collapse or global sclerosis, hyalinosis, and fibrosis) in control rats, or rats receiving $\mathrm{N}$-desulfated/acetylated heparin or standard beef lung heparin. Bars represent the mean \pm standard error of the mean. The number of abnormal glomeruli was significantly greater in control rats than in rats receiving $\mathrm{N}$-desulfated/acetylated heparin or standard heparin $(P<0.001)$. There was no signifant difference in the number of abnormal glomeruli between the two groups of rats treated with heparin $(P>0.05)$. devoid of anticoagulant properties. Treatment with intact heparin resulted in elimination of the animals' albuminuria, reduction in blood pressure, and improved renal morphology. By contrast, the lower molecular weight fraction of heparin decreased the degree of albuminuria but did not reduce the severity of the morphologic damage as compared with untreated controls. Although at first examination the results of Olson's experiments (4) suggest that anticoagulation is necessary for the protection afforded by heparin in this model, note that the low molecular weight fraction of heparin used by Olson (4) may not have retained some of the other pharmacological actions of intact heparin.

It is tempting to suggest that the decrease in renal histological damage observed with heparin administration is due to a decrease in systemic blood pressure. However, this seems unlikely since in a previous study (2) we demonstrated that despite a comparable decrease in systemic blood pressure achieved with heparin or with antihypertensive drugs (a combination of reserpine, hydralazine, and hydrochlorothiazide), the heparin-treated rats had $\sim 2 \%$ sclerosed glomeruli on histological examination as compared with $20 \%$ sclerosed glomeruli in the group treated with antihypertensives. We have also reported in abstract form (15) that Munich-Wistar rats with subtotal nephrectomy had a considerably lesser number of sclerosed glomeruli at 4 and 7.5 wk after surgery than control rats despite the persistence of similarly elevated values for glomerular plasma flows and intraglomerular pressure at 2 and 4 wk in both groups of rats. Since in our hands the renal histological changes, after subtotal nephrectomy, of MunichWistar rats is identical to that of Sprague-Dawley rats, and since glomerular hypertension precedes the development of histological damage to glomeruli (3), it seems likely that heparin provides protection against structural glomerular damage by a mechanism independent of changes in intraglomerular pressure. In addition, as discussed below, heparin has been shown recently to have a beneficial effect on renal histology in a model of chronic aminonucleoside nephrosis in which sys- 
temic hypertension is not present (16). Thus, it seems unlikely that the decrease in systemic blood pressure produced by heparin in this study is responsible for the protective effect on glomerular structure seen in the rats treated with this compound.

The results of the present experiments indicate that N-desulfated/acetylated heparin, almost completely devoid of anticoagulant properties, ameliorates the progression of renal disease in rats with subtotal nephrectomy. The degree of protection afforded by $\mathrm{N}$-desulfated/acetylated heparin was similar to that provided by the administration of standard beef lung heparin. These results indicate that heparin produces a beneficial effect on the progression of renal disease by mechanisms that may be independent of those related to its anticoagulant properties. It may be argued that the small degree of anticoagulation produced by $\mathrm{N}$-desulfated/acetylated heparin in vivo was responsible for the effects seen. Although there were no differences in aPTT between normal rats given saline or $\mathrm{N}$-desulfated/acetylated heparin, there was a slight but significant difference in the aPTT between $13 / 4$ nephrectomized rats that received saline and those given $\mathrm{N}$-desulfated/acetylated heparin (see Table I). However, note that anticoagulation with other agents, such as warfarin, resulted in a marked prolongation of the prothrombin time but did not afford the same degree of functional or histological protection seen with the use of N-desulfated/acetylated heparin $(5,6)$. In addition, anticoagulation with warfarin did not decrease systemic blood pressure to the same extent as $\mathrm{N}$-desulfated/acetylated heparin, suggesting that heparin may have its major effects through mechanisms that are independent of its anticoagulant properties.

Heparin has been shown to have many pharmacologic effects that could modify the course of the glomerular lesions seen in the model of subtotal renal ablation. Inactivation of plasma proteases including clotting Factors XII, XI, IX, X, and thrombin produces an anticoagulated state (8). Inhibition of another serum protease, renal kallikrein, may decrease production of renin or cause alterations in renal blood flow (17). However, this was not observed in experiments that examined the effects of anticoagulant heparin on renal hemodynamics (15). The negative electrical potential of the vascular wall may be secondarily increased by the binding of heparin, a polyanionic molecule, to endothelial surfaces $(7,18)$. However, in the studies of Olson (4) it was shown that a low molecular weight fragment of heparin failed to prevent histological damage, although it decreased the degree of proteinuria.

Recently, Diamond and Karnovsky (16) have assessed the efficacy of anticoagulant and nonanticoagulant heparin on the proteinuria, decrease in renal function, and development of glomerulosclerosis that occurs in rats given a single intravenous injection of the aminonucleoside of puromycin. Both standard heparin given at a dose that did not prolong the activated thromboplastin time and a fragment of heparin with a molecular weight of 7,000 to 11,000 , devoid of anticoagulant properties, ameliorated the functional and histologic abnormalities in this experimental model of renal disease. Chronic aminonucleoside nephrosis is not accompanied by systemic hypertension. Furthermore, Diamond and Karnovsky (16) found that blood pressure in their heparin-treated rats was not different from controls and suggested that the protection afforded by heparin in this model was not mediated through an antihypertensive effect.
Heparin has been shown to suppress smooth muscle cell proliferation in arteries (19-21). This effect is retained in heparin devoid of anticoagulant properties (20). Note than an $\mathrm{N}$ desulfated reacetylated heparin prepared in a manner similar to the preparation used in the current study has been demonstrated to inhibit the proliferation of vascular smooth muscle cells in vitro (22). Exogenous heparin added to culture medium inhibited proliferation of both exponentially growing mesangial cells and mesangial cells released from growth arrest (23). Therefore, a major effect of both N-desulfated/acetylated and standard heparin in this animal model of renal disease may be related to the antiproliferative properties of these compounds on mesangial cells. Note, as mentioned above, that nonanticoagulant heparin retains the antiproliferative effects of native heparin. In addition, Castellot et al. (23) noted that conditioned media from glomerular epithelial cells possesses an inhibitor of mesangial cell growth and that this substance has heparin-like properties. Fishman and Karnovsky (24) have also shown in vitro that the glomerular epithelial cell is both morphologically and functionally injured in several disease states including the nephrosis produced by the aminonucleoside of puromycin. Epithelial cell lesions also occur in the remnant kidney model (3). Consequently, decreased production by injured epithelial cells of a heparin-like compound, which normally inhibits mesangial cell growth and proliferation, may lead to mesangial expansion and increased synthesis of mesangial matrix. Exogenous heparin administration may provide the necessary concentrations at the glomerular level to prevent mesangial proliferation.

\section{Acknowledgments}

The secretarial assistance of Ms. Pat Verplancke is gratefully acknowledged.

The studies reported here were supported by U. S. Public Health Service grants DK-09976 (to S. Klahr), DK-07126 (to S. Klahr), and HL-14147 (to D. M. Tollefsen), and by a grant from the Monsanto Co. (to D. M. Tollefsen).

\section{References}

1. Shimamura, T., and A. B. Morrison. 1975. A progressive glomerulosclerosis occurring in partial five-sixths nephrectomized rats. Am. J. Pathol. 79:95-106.

2. Purkerson, M. L., P. E. Hoffsten, and S. Klahr. 1976. Pathogenesis of the glomerulopathy associated with renal infarction in rats. Kidney Int. 9:407-417.

3. Rennke, H. G. 1986. Structural alterations associated with glomerular hyperfiltration. In The Progressive Nature of Renal Disease. W. E. Mitch, B. M. Brenner, and J. H. Stein, editors. Churchill Livingstone, Inc., New York. 111-131.

4. Olson, J. L. 1984. Role of heparin as a protective agent following reduction of renal mass. Kidney Int. 25:376-382.

5. Purkerson, M. L., J. H. Joist, J. M. Greenberg, D. Kay, P. E. Hoffsten, and S. Klahr. 1982. Inhibition by anticoagulant drugs of the progressive hypertension and uremia associated with renal infarction in rats. Thromb. Res. 26:227-240.

6. Klahr, S., M. Heifets, and M. L. Purkerson. 1986. The influence of anticoagulation on the progression of experimental renal disease. In The Progressive Nature of Renal Disease. W. E. Mitch, B. M. Brenner, and J. H. Stein, editors. Churchill Livingston, Inc., New York. 45-64.

7. Jaques, L. B. 1979. Heparin: an old drug with a new paradigm. Science (Wash. DC). 206:528-533. 
8. Rosenberg, R. D. 1977. Biologic actions of heparin. Semin. Hematol. 14:427-440.

9. Inoue, Y., and K. Nagasawa. 1976. Selective N-desulfation of heparin with dimethyl sulfoxide containing water or methanol. Carbohydr. Res. 46:87-95.

10. Hook, M., J. Riesenfeld, and U. Lindahl. 1982. N-[ $\left.{ }^{3} \mathrm{H}\right]$ Acetyllabeling, a convenient method for radiolabeling of glycosaminoglycans. Anal. Biochem. 119:236-245.

11. Bitter, T., and H. M. Muir. 1962. A modified uronic acid carbazole reaction. Anal. Biochem. 4:330-334.

12. Tollefsen, D. M., D. W. Majerus, and M. K. Blank. 1982. Heparin cofactor II. Purification and properties of a heparin-dependent inhibitor of thrombin in human plasma. J. Biol. Chem. 257:2162-2169.

13. Koletsky, S., and A. M. Goodsitt. 1960. Natural history and pathogenesis of renal ablation hypertension. Arch. Pathol. 69:654-662.

14. Purkerson, M. L., J. H. Joist, J. Yates, A. Valdes, A. Morrison, and S. Klahr. 1985. Inhibition of thromboxane synthesis ameliorates the progressive kidney disease of rats with subtotal renal ablation. Proc. Natl. Acad. Sci. USA. 82:193-197.

15. Ichikawa, I., Y. Yoshida, M. L. Purkerson, and S. Klahr. 1986. Heparin prevents renal failure, glomerular damage and systemic hypertension despite glomerular hypertension in remnant nephrons. Proc. Am. Soc. Hypertension. 32A. (Abstr.)

16. Diamond, J. R., and M. J. Karnovsky. 1986. Non-anticoagulant protective effect of heparin in chronic aminonucleoside nephrosis. Renal Physiol. 9:366-374.
17. Nasjletti, A., and K. U. Malik. 1981. Renal kinin-prostaglandin relationships: implication for renal function. Kidney Int. 19:860-868.

18. Hiebert, L. M. 1979. Heparin and endothelium. In Heparin: Structure, Cellular Function and Clinical Applications. N. M. McDuffie, editor. Academic Press, Inc., New York. 289-297.

19. Clowes, A. W., and M. J. Karnovsky. 1977. Suppression by heparin of smooth muscle cell proliferation in injured arteries. Nature (Lond.). 265:625-626.

20. Guyton, J. R., R. D. Rosenberg, A. W. Clowes, and M. J. Karnovsky. 1980. Inhibition of rat arterial smooth muscle cell proliferation by heparin. I. In vivo studies with anticoagulant and non-anticoagulant heparin. Circ. Res. 46:625-634.

21. Hoover, R. L., R. D. Rosenberg, W. Haering, and M. J. Karnovsky. 1980. Inhibition of rat arterial smooth muscle cell proliferation by heparin. II. In vivo studies. Circ. Res. 47:578-583.

22. Castellot, J. J., D. L. Beeler, R. D. Rosenberg, and M. J. Karnovsky. 1984. Structural determinants of the capacity of heparin to inhibit the proliferation of vascular smooth muscle cells. J. Cell. Physiol. 120:315-320.

23. Castellot, J. J., R. L. Hoover, P. A. Harper, and M. J. Karnovsky. 1985. Heparin and glomerular epithelial cell-secreted heparinlike species inhibit mesangial-cell proliferation. Am. J. Pathol. 120:427-435.

24. Fishman, J. A., and M. J. Karnovsky. 1985. Effects of the aminonucleoside of puromycin on glomerular epithelial cells in vitro. Am. J. Pathol. 118:398-407. 